reticulin, and it has been suggested that they have an important effect on the erector pili muscles in the skin. It seems not unlikely that, in the future, bates may be made up with specified enzymes, so that the different proteins of the skin may be preferentially attacked according to the class of leather desired.

Bacteria are notorious in the industry as the cause of putrefaction and, in the form of anthrax, as a danger to operatives. In their paper on this aspect, Dr. M. E. Robertson and Miss B. M. Haines said that putrefaction is usually prevented either by drying the hides after flaying or by treating them with sodium chloride as a preservative. The treatment of hides with a salt of marine origin, however, is likely to encourage a growth of red halophilic bacteria, known to tanners as 'red heat'; but this can be prevented by the addition of sodium fluoride to the salt. The use of disinfectants is also recommended in the process known as soaking, during which bacterial damage is especially common. The important process of liming kills all active stages of bacteria, but some spores (including those of anthrax) can survive; these can be killed by 'drumming' in lime and sodium sulphide at a raised temperature. Bacteria can, however, sometimes be of use to the industry : in America, bacteria producing lactic acid are used to promote the necessary acidity in the tan liquors, but in Great Britain the method is regarded as too difficult to control.

During many of the stages from skin to finished leather, mould fungi occur : except as a source of bating enzymes, they are a nuisance. The industry has also its insect pests, the chief being, perhaps, the beetles of the genus Dermestes. Mr. A. J. Musgrave, dealing with mycological and entomological problems, outlined the damage caused by fungi in the various processes. It is well known that vegetable-tanned leather is a better substrate for fungal growth than that which has been chrome-tanned; but the kind of processing a leather has received affects its liability to mould growth ; moreover, there is need for a fuller acquaintance with the species of fungi that occur in the industry, and of the damage that they cause. A number of fungicides are available to the industry, which has wisely made use of available knowledge; and there are various ways in which fungicides can be incorporated in leather, though its multifarious uses make every proofing problem worthy of individual attention.

A considerable number of insects associated with the industry has been recorded. The chief pests seem to be warble flies, attacking the living skin, Dermestes beetles on dried hides, clothes-moths and carpet beetles on furs, and various insects attacking leather in the tropics. In addition, the fly Piophila casei is a considerable nuisance. It appears that the most systematic efforts at control have been those directed against Dermestes beetles : for many years arsenication of dried hides has been practised. The difficulties encountered in carrying out laboratory tests on insecticides and fungicides for the industry were discussed : some simple preliminary experiments have indicated that 'Gammexane' may be more toxic than D.D.T. to Dermestes maculatus.

Finally, when the leather has been manufactured, it may be found to be faulty in some way, or a tanner may realize during manufacture that there is some irregularity. A method in leather biology that is indispensable in investigating these faults and in controlling the various processes is a specialized branch of animal histology : the study of the fibre structure of skins and leather. In dealing with this subject, Miss M. Dempsey stipulated that it is the task of the student of fibre structure to attempt to correlate what he sees with the physical properties of the leather and with the kind of processing it has undergone. The condition of the collagen fibre bundles and their manner of interweaving constitutes, sensu strictu, the fibre structure of the leather : the history of a leather is written in the appearance of its fibre bundles. The properties of a leather, she said, are dependent on its fibre structure, the appearance of which not only gives information about the suitability of a process, but also indicates the quality of the leather, and, more important still, may reveal the cause of a flaw, such, for example, as skin disease or putrefaction, chemical breakdown during manufacture or maltreatment in use. The various features of fibre structure were described and their practical importance indicated.

A fuller account of this meeting is to be published in the Annals of Applied Biology.

\section{RESEARCH AND INDUSTRY IN SCOTLAND}

$\mathrm{T}$ HE Scottish Regional Conference on "Research and the Progress of Industry in Scotland" arranged by the Federation of British Industries and held at the Merchants' Hall, Glasgow, on April 25, was on similar lines to that of the Midlands Regional Conference of the Federation at Birmingham in March. A message from Sir Edward Appleton wishing the Conference success contained, however, perhaps the most important statement made there. After indicating that the Department of Scientific and Industrial Research had been giving a good deal of attention to the question of the diffusion of scientific knowledge, and was looking to these conferences for guidance as to how best to deploy the limited scientific effort of Great Britain, Sir Edward said that to improve the Department's contacts with Scottish industry it is arranging to open a Scottish branch of the recently created Intelligence Division; and he cordially invited firms to discuss their special problems with the Department when that branch had been opened.

The morning session of the Conference considered the established industries of the region, Mr. W. Barr dealing with research in the steel industry, followed by Sir Wilfred Ayre on research in the shipbuilding industry and Mr. W. G. Marshall on research in the heavy engineering industries. Mr. Barr referred particularly to the recruitment of workers with technical knowledge in order that the results of research may be utilized. Steelmaking, so long practised as an art, is slowly becoming a science founded on the laws of physical chemistry, but much remains to be done before the desirable degree of control throughout the process is attained. Sir Wilfred Ayre, pointing out that the Scottish industry should not be differentiated from the larger British shipbuilding industry of which it is a part, suggested that the application of science in the industry would be facilitated if firms were readier to present the results of their research either in papers before technical institutions or to the industry's research association. He referred particularly to the valuable contribution of the various technical institutions, as well as to the work of the classification societies, and to the important 
part which the technical colleges might take in research. Private firms, however, must continue increasingly to carry out scientific work for themselves, and increasing numbers of their technical staff will require a more scientific training; and he stressed the need for planning so as to ensure that research work is at all times adequately prosecuted undisturbed by fluctuations in the prosperity of the industry. Commenting on the special problems of Scottish heavy industry, Mr. Marshall emphasized its comparative isolation from other industrial areas, the lack of variety of technical facilities, and of the skilled manpower and brain-power provided by light industry. It is thus the more important that the industry should make the fullest use of existing technical facilities. After reviewing the functions of an industrial research department, including the necessity of keeping abreast of research and development work elsewhere, and the qualifications of its staff, he briefly outlined the problems with which the research department of Messrs. Babcock and Wilcox, Ltd., is concerned. No section is entirely devoted either to routine or to research, and physics is of increasing importance in almost every branch of technology.

At the afternoon session, which considered broadly the balancing of Scotland's industries, Dr. J. W. McDavid reviewed the experience of the Explosives Division of Imperial Chemical Industries, Ltd., with nitrocellulose finishes, 'Cellofas', ethylcellulose, pentaerythritol, 'Ardil', etc., to indicate the way in which a live research and development department leads to new manufactures loosely but logically connected with the main industry. Dr. W. M. Cummings' paper, "Chemical Research for Scottish Industry", considered especially the needs of the small manufacturer who is characteristic of the region. The region is not big enough industrially to have several different research organisations, and while Dr. Cummings referred to the idea of establishing a research organisation in Scotland, working in close association with the Department of Scientific and Industrial Research, covering all branches of industry, engineering, building, coal, food, etc., he appeared to look rather to the technical colleges for greater assistance, and in particular he commended the example of the Joint Research Council established in Manchester. The idea could be extended with advantage in other areas, and should promote the contacts between industry and the technical colleges and universities which are all-important.

Mr. J. N. Toothill, discussing "Research in the Light Engineering Industries", commented on the effect of research and development on export policy and its assistance in securing balanced employment. It also helps to raise the standard of living of the community, and it can be an important factor in determining the location of industry. Mr. Toothill dealt with this idea in some detail, suggesting that in a new light industry, the growth of new products arising out of technical discoveries and appreciation of their market possibilities, and communications with market centres and centres of research, are more important influences on the location of industry than the supply of cheap raw material, adequate modern factory facilities and adequate, cheap and reliable supplies of electric power. At present, Scotland employs only $2 \cdot 5$ per cent of the total scientific man-power of the United Kingdom, as against a working population of 10 per cent, and new industries fail to grow in all areas distant from London. In this connexion, he referred to the tendency in the
United States, and to some extent in Great Britain, to segregate the direction of policy, market research and technical research in areas near the national headquarters, leaving production to be carried out where labour is available.

In the final paper of the Conference, Prof. R. Hay, reviewing the individual Scottish firm and its application of research, pointed out that the first essential is a desire on the part of firms to utilize the advances already made in technical research. For small firms he suggested first the engagement of a professional consultant. For larger firms a technical development officer might be employed as technical adviser to the head of the firm, working in conjunction with established research associations, possibly supplemented by a small staff of his own. To meet the dearth of qualified men a co-operative effort of technical colleges and industry would be required, while finally Prof. Hay urged that industry in Scotland could with advantage develop a research centre on the lines of the Mellon Institute.

\section{EMISSION OF RADIO-WAVES BY THE GALAXY AND THE SUN}

\section{BY JOSEPH S. SHKLOVSKY}

Sternberg Astronomical Institute of the Moscow State University

1 HE remarkable investigations of Reber', Southworth $^{2}$ and Appleton ${ }^{3}$ have shown that radiowaves in the metre and centimetre region are emitted by the galaxy and the sun. Henyey's and Keenan's theory of long-wave emission by the galaxy ${ }^{4}$ is based on the assumption that the mechanism of this emission is a free-free emission from interstellar gas. However, they have not correctly accounted for the absorption of radio-waves in the galaxy. Besides free-free absorption (which Henyey and Keenan took into account), there is an ordinary absorption of radio-waves because of damping oscillations of electrons in the field of radio-waves. The coefficient of absorption is given by

$$
\alpha_{y}=\frac{\pi e^{2} N_{e}}{m} \cdot \frac{1}{c} \frac{\gamma}{4 \pi v^{2}+(\gamma / 2)^{2}} .
$$

In interstellar space (and even more so in the solar atmosphere) the constant of damping $\gamma$ is determined by the collision of electrons with ions. In this case

$$
\gamma=4 N_{i} \sqrt{\frac{2 \pi k T_{\varepsilon}}{m}} \cdot \frac{\pi}{2} \frac{e^{4}}{\left(k T_{\varepsilon}\right)^{2}} \ln \left(\frac{3}{2} \frac{k T_{\varepsilon}}{\left.e^{2} N_{e}\right)^{1 / 3}}\right),
$$

where $N_{i}=N_{e}$, the concentration of ions, and $T_{\varepsilon}$ is the electron temperature.

Solving the equation of transfer, we get the following expression for the intensity of galactic radioemission :

$$
I_{\nu}=\frac{2 \nu^{2} k T_{\varepsilon}}{c^{2}}\left(1-e^{-\tau_{v}}\right)
$$

where $\tau_{v}$ is the optical depth of the galaxy in a given direction. Here the coefficient of absorption is accounted for in the above-mentioned manner.

Each intensity of a given optical depth of the galaxy in a given direction measured by Reber can be brought to a mutual correspondence. Assuming that $T_{\varepsilon}=10,000^{\circ}$, we find that the above-mentioned $\tau_{\nu}$ changes from $\mathbf{0 . 4 8}$ (in Sagittarius, where the intensity is the highest) to 0.008 (in Perseus). For most regions of the Milky Way $\tau_{\nu}$ is less than $0 \cdot 1$. 